\title{
Cognitive Ergonomics and Production Information Systems under the gaze of interdisciplinary Design or Industrial Design
}

\author{
Luciene Bulhões Mattos ${ }^{\mathrm{a}, *}$ \\ ${ }^{a}$ Instituto Federal de Educação, Ciência e Tecnologia da Bahia-IFBA, Bahia, Brasil
}

\begin{abstract}
The core of this work involves the study of cognitive ergonomics and production of Information Systems under the interdisciplinary of the Design or Industrial Design. It is assumed that in the dynamics of human and the systems, mediated by systematic technology, there are constant changes in social perceptions, that alter the shape of the subject dealing with the real world, concrete, adopting a pseudo-idea of the evolutionary process. Attentive to the interdisciplinary and transdisciplinary groups as agents of this process, points to the danger of the emergence of the myth of innovation as a solver of social problems and suggests new ergonomics as a contributor in a different way of thinking the humanization beyond of the XXI century.
\end{abstract}

Keywords: Psychology; Technology; Human-Sytematization; Transdisciplinary

\section{Introduction}

"Quanto mais as linguagens se enriquecem e se estendem, maiores são as possibilidades de simular, imaginar, fazer imaginar um alhures ou uma alteridade."

Pierre Lèvy

The core of this work involves the study of cognitive ergonomics and production of Information Systems under the interdisciplinary of the Design or Industrial Design. It is considered that ergonomics is a science or a sequence of investigative techniques applied in various areas of knowledge, from the Humanities and Social Sciences, to the Engineering and Life Sciences.

The technology involves processes of change according to each innovation, in which both the Humanities, and the Engineering and Applied Social Sciences need to restructure their theoretical approaches in the case of the first, and the theoretical and practical approaches in last cases.
The text begins with what is regarded as the first challenge of Design and Ergonomics: transdisciplinarity or the utopia of the whole. Then he points to factors that contribute to a relationship between man and systematic perspective. Follows a trend to the study of cognitive processes that involve this utopian way of dealing with problems involving man and the world through technology.

Finally, he suggests that the elements involving the pair man-systemizing go beyond the iconic manmachine vision, seeking in the study of human factors dedicated to information systems, the various problems that affect the nature, man and the knowns.

\section{Industrial Design, Information Systems and Language: the transdisciplinary groups}

Industrial Design or Design is becoming increasingly a restorative element of the areas of knowledge which make up languages that interpret (respecting the prematurity of the Design in relation to other areas of knowledge involved) and produces new information systems within transdisciplinary groups.

\footnotetext{
*E-mail: lueta@ifba.edu.br ; Endereço: Rua Vereador José Barbosa dos Reis, 162, Cond. Pedras do Mar, cs 12, Ipitanga - Lauro de FreitasBahia, CEP: 42700-000
} 
It's believed that the creative process of design when coupled with information systems, the behavior study of user and the consequences of the his actions reflect what the human being inferred by technology. In this context that emerges the Cognitive Ergonomics.

\section{The Relationship Man-Systematization}

The claim is that to adapt to a new form of dialectical (i)materialism that accompanies it in recent decades, the subject mediated by technology is subject to what he infers, establishing new dynamic forms of cause and effect.

The culmination of thought and action in human-computer interface causes mutations between perceptions of social replacing the human-machine interface between human and systematization, determining a pragmatic model that calls for the dissolution of thought and action height.

\section{The Myth of Innovation}

There is some element that is lost and this element seems circular or groping in the dynamics of man and his environment through systematic technologies. Even though the technology invisible (wifi or wireless features) that predispose the reading of thought in action, the feeling of having no social control in real-world concrete, which is given by the virtual environment, reveals the technological impact of this century. It is as if there are many technologies, once the tools, instruments, etc.., refined and adapted to work with some human needs for pseudo-problems or just problems facing the market logic.

Users of digital information systems still do not realize how these factors may affect the evolutionary process. It is not contemporary change through information technology and speed, a condition for knowledge or condition of man can reach the pinnacle of civilization, but the human ability to come and go in this process of changing, modifying or creating new rules, with a tendency to make substrates for mechanisms and steps to avoid compromising the physical, mental and psychological human.

\section{The Research}

\subsection{A qualitative research}

This is a qualitative research that also takes into account the quantitative aspects, which are considered both the elements of scientific research as the elements of research design.

\subsection{General Objective}

The general objective is understand how the relationship human-computer contribute to the emergence of man-systematization generation, relationship in which thought and action overlap each other and determine ways to realize an extemporaneous immaterial world.

\subsubsection{Specifics Objectives}

- to detect aspects described by cognitive ergonomics that manifest themselves in mansystematization;

- to differ between the human evolutionary process marked by physical changes, mentals and psychologicals, and technological change, i. e., the process by which changes occur between the real-concrete, abstraction and imagine, with the computer as medium;

- to seek elements of Design Research Methodology that promote the interdisciplinary or transdisciplinarity;

- outline a new look at the relationship between man and systematization.

\subsubsection{Date and Data collection}

One use secondary data such as books, papers, journals, reviews and electronic articles, websites, videos, etc. Data collection is done through observation of information systems chosen (when applicable), of questionnaires, conversations with researchers.

\subsubsection{Data Processing}

The data processing takes place according to each specific type of data, considering the kind of research and interdisciplinary nature of Sciences, Technology and Design. 


\section{Finals considerations}

It is possible to study cognition beyond compare human and machine, user-computer, which models the desired object on the machine, computer system, robot, seeking human perfection as did the ancient Greeks. This thinking resulted in the idea of perfection in art. It is necessary think of another way of humanization. This should be the contribution of ergonomics that goes beyond the twenty-first century.

\section{References}

[1] H. Maturana, Transdisciplinaridade e Cognição, in: CETRANS (1 ${ }^{\mathrm{a}}$. Edição da UNESCO) Educação e Transdisciplinaridade. São Paulo: TRIOM, 1999. Available in: http://www.ia.ufrrj.br/ppgea/conteudo/T1SF/Akiko/08.doc, Acess: 09/2011.

[2] Jean-Marc Robert. Cognition située, cognition distribuée et cognition socialement partagée, École Polytechnique de Montréal, 2011. Available in: http://docs.google.com/ , Acess: 08/2011.

[3] M. Dawson and D. Meddler. Dictionary of Cognitive Science., Available in: http://www.bcp.psych.ualberta.ca/ mike/Pearl_Street/Dictiona ry/contents/C/index.html , Acess: 08/2011.

[4] P. LÈVY. O que é o virtual, Ed. 34: 1996.

[5] P. Weil et al, A crise da fragmentação: gênese e propostas de solução, in: Rumo à nova transdisciplinaridade, São Paulo: Summus, 1993. Available in: http://books.google.com.br, Acess: 09/2011.

[6] STANFORD ENCICLOPEDIA OF PHILOSOPHY. Cognitive Science, Available in http://plato.stanford.edu/entries/cognitive-science/\#Rep , Acess: 08/2011.

[7] Stuart K. Card,Thomas P. Moran and Allen Newell. The psychology of human-computer interaction, LEA: 1983. Available in: http://books.google.com.br/

[8] T. Armstrong. Multiple Intelligences, Available in: http://www.thomasarmstrong.com/multiple intelligences.php

[9] University of Westminster. Cognitive styles, Available in: http://www2.wmin.ac.uk/eic/learningskills/cognition/learning_styles/cogn_styles.html, Acess: 08/2011. 